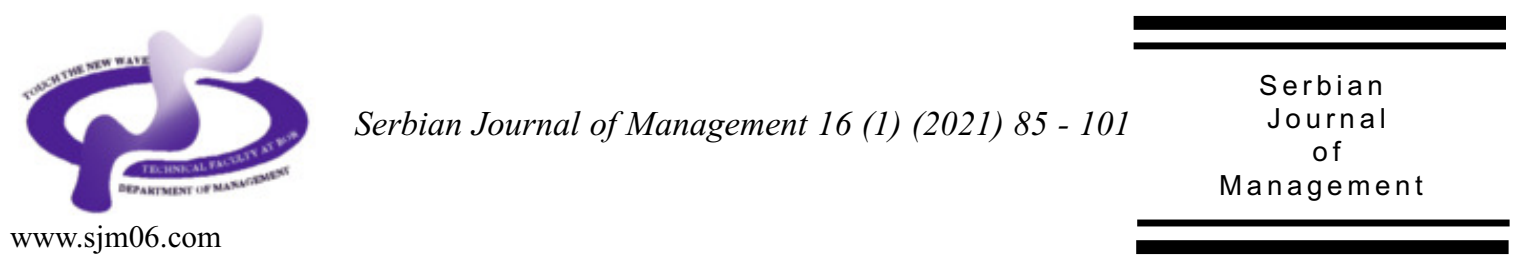

\title{
INFORMATION AND COMMUNICATIONS TECHNOLOGIES AND MULTIMEDIA CONTENT AS MOTIVATIONAL FACTORS FOR NEW GENERATIONS OF STUDENTS
}

\author{
Marija Marković Blagojević*, Zorica Medić, Maja Cogoljević and \\ Raica Milićević
}

Faculty of Business Economics and Entrepreneurship Belgrade, Vojvode Vlahovića 35b, 11000 Beograd

(Received 05 May 2020; accepted 01 September 2020)

\begin{abstract}
This paper deals with the theoretical analysis of the principles of efficient use of information and communications technologies (ICT) in teaching and learning, which can contribute to the advancement of the teaching process and motivation of students/pupils in the achieving the planned activities. Apart from the theoretical analysis, the results of empirical research are also presented in the paper. They tested and practically confirmed that there is a significant influence of the application of ICT and enriching the teaching material with multimedia content and also the effects in contemporary teaching of information technology. The primary intention of this paper is to point out the importance of the introduction of ICT to the teaching process with the aim of a significant improvement of students'/pupils' learning through the increase of their motivation and efficiency in learning, and at the same time the improvement in the performance of the educational system.
\end{abstract}

Keywords: ICT, education, advancement of teaching, multimedia content, efficient learning

\section{INTRODUCTION}

Globalization has conditioned new ways of knowledge acquiring, that is, training and education in general, partly due to the improvement of the traditional methods of knowledge collecting but also transferring the new skills and tools (Naps et al., 1997).
Exactly for the sake of improving the teaching process, the presence of ICT has been increasing through multimedia content (Nabil et al., 1997). Cheng and collaborators point out that multimedia content has the possibility to advance the learning performances by improving the satisfaction and engagement of users (Cheng et al.,

\footnotetext{
* Corresponding author: mmarrija@gmail.com
}

DOI: $10.5937 /$ sjm16-26433 
2009). Multimedia content gives a better presentation of the concept, which is not possible in conventional forms.

The essence of ICT application and presentation of teaching units through multimedia content is in the fact that it motivates students for working, first with its design, to create an inner need for acquiring knowledge and enabling the real thinking activity, which implies problem solution and conscious knowledge application in different and new situations (Cekić-Jovanović, 2015).

Teaching materials presented this way are far more accessible to each student. The fan of didactic material including e-books, hypertexts, photo galleries, databases, animations, video clips, presentations, and similar, enables the student to observe, listen, think and perform certain actions at the same time (Chittaro \& Ranon, 2007).

The ICT application in teaching requires certain competencies of teachers, i.e. digital literacy, or as it has been called lately the digital competence of teachers (Marković Blagojević et al., 2019). Digital competence is related to being trained for the safe and critical use of ICT for work and communication. Key skills and abilities can be seen through the use of computers for finding, evaluating, creating, archiving, presentation, and sharing information, as well as social interaction by the use of the internet and social networks.

Still, as Mayer states, even with the existence of proof that the ICT application contributes to the quality increase of the teaching process and acquiring knowledge with students, not all the uses of multimedia content are equally effective (Mayer, 2017). The teacher's role is to continually follow the results of his students and to adapt the use of multimedia content to the group and reported results. Badly designed and organized teaching content creates more difficulties for a student (pupil), not related to the subject they should learn (Pavić, 2019).

ICT is undeniably a part of life of many, though all the people do not have the same approach to what is available, nor the benefits are divided equally. The same goes for education, which is confirmed by world researches.

Polemics about ICT in education has spread in so many directions that, as Biesta suggests, "it is not only hard to get the correct review of what is going on, but it has also become very hard to give a significant contribution to it", (Biesta, 2016).

By the conducted research of the European Commission in 2011 by the name of "European survey of schools: ICT and education - ESSIE", 27 countries were comprised and more than 190000 teachers employed in educational institutions were surveyed. According to the report of the European Commission, some of the findings are that the "students and teachers in Europe want to become "digital", the use of ICT in teaching and the level of digital skills are very uneven, and there are significant differences between the countries. The report on the research has also shown that $95 \%$ of students attend schools where the teaching staff has a positive attitude towards the application of ICT and the belief that its application should become a part of learning," (Buda, 2014).

"Virtual schools in the USA have enormous yearly rates of enrollment growth from 50000 in the year 2000, to more than 500000 so far - North American Council for Online Learning [NACOL]" (Patrick, 2008).

TALIS research (Teaching and Learning International Survey) carried out in 2018 - is international research about education and 
learning which represents the world evaluation of teaching and learning conditions, coordinated by the Organization for Economic Co-operation and Development (OECD) in order to improve the educational policies and outcomes comprised the countries members of OECD and the USA, where the representative sample included about 260.000 surveyed teachers in 48 participating countries. By the report of TALIS from 2019, the following results are noticeable (OECD, 2019).

Despite the prevalence of ICT in the everyday life, these technologies still have not been so much adopted in formal education, but their influence on performances of students where they are used in classrooms is mixed, at best.

-The countries with the largest integration of ICT in schools are Australia, Denmark, the Netherlands, and Norway, and there is a fast growth of participation of students doing school tasks on computers in Australia, Chile, Greece, New Zealand, Sweden, and Uruguay.

-In Australia, Austria, Canada, Czech Republic, Iceland, Macau, New Zealand, Great Britain, and the USA there is at least one computer per student, and at least $95 \%$ of them are connected. Opposite to that, in Albania, Algeria, Indonesia and Tunisia there is less than one computer on every five students, and less than $70 \%$ are connected.

-Students in Australia, Brazil, Korea, Singapore, Sweden, and the USA manage digital reading better than the reading of printed material.

-The more students play online games, the worse their relative performance in reading printed material is. However, these negative effects can be leveled by the positive effects on their ability to navigate through digital texts.
-In the USA $60 \%$ of teachers on average allow students "often" or "always" to use ICT for projects or group work, which is above the average of the OECD countries $(53 \%)$.

-In the USA, $63 \%$ of teachers said that "the use of ICT in teaching" is included in their formal education or training, which is significantly above the average of OECD $(56 \%)$.

-Only $42 \%$ of students in Korea and 38\% of students in Shanghai - China applied to use computers at schools - and they used to be the leading countries/economies in digital reading and evaluation of Maths based on computers on the OECD for the International evaluation of students (PISA) in 2012.

All things considered, the relation between the use of computers at school and performances is graphically illustrated by the shape of a hill, which suggests that the limited use of computers at schools is perhaps better than no use at all. On the other hand, in countries comprised by the TALIS research, $20 \%$ of teachers said that there was a high level of need for the development of their ICT skills for teaching, which was also confirmed by the research of the author further on in the paper.

The researchers Bacaron and Cantona (2018) state that students who were exposed to learning by the application of multimedia through a constructive approach by their research are more interested and motivated for the planned educational content, and the results of the study show that the students evaluated the application of multimedia in teaching through a constructive approach as interesting, motivating and efficient. The same was confirmed as well by the carried out research of the author further on in the paper.

Ilhan and Oruç (2016) state in their study 
that multimedia increases the success of students. They also state that Akin and Cecen (2015) analyzed the opinions of students of primary schools about multimedia tools and it was established by the research that the use of multimedia in the learning process not only increases the level of success of students, but it also creates positive changes in the attitude of students toward classes. Moreover, the researchers noticed that the motivation of students increased after the performed research and the application of multimedia. The mentioned authors also conclude that it could be stated that the use of multimedia increases the success and motivation of students and at the same time positively influences the attitude of students toward teaching materials. The paper authors have also confirmed the stated conclusions by their research, and the results are given further on in the text of the paper.

By the above stated, the aim of the paper is to perceive the opinion of students in the Republic of Serbia from the aspect of the contemporary way of learning, about the process of transfer and acquiring knowledge by the application of information and communications technologies.

\section{STRATEGIC FRAME AND THEORETICAL ANALYSIS OF THE PRINCIPLES OF ICT APPLICATION IN TEACHING}

Strategic frame for the application of ICT in education is the Strategy of education development in Serbia until 2020, by which the following priorities were determined: the academic computer network, ICT in education, researches, and innovations in the field of ICT and digital content. It proclaims the necessary integrating of ICT in all the aspects of the educational process, with the aim of more effective and efficient education (The strategy of education development in Serbia until 2020, 2012).

The use of ICT in teaching has huge potential for creating a high-quality environment for learning. The key elements can be seen through the control of users in giving information and in the possibility of using interactivity for the improvement of the learning process through creating an integrated environment for learning (Cairncross \& Mannion, 2001).

By the application of ICT in educational institutions, the role of the teacher in the organization of teaching is primarily changing, then the role of students/pupils, and finally the aspect of resources which should be used in contemporary approaches in the educational process. (MatijaševićObradović et al., 2018).

"It is a widespread opinion in literature that the active acquiring of knowledge in teaching can be achieved only if the participants individually use sources of knowledge, solve problems, learn by the model of discovery, describe independently, search for analogies, synthesize and systematize teaching content they learn, change the circumstances, find new and unusual ideas", (Budić, 2006). The new foundations of education are exactly built on the mentioned opinions.

By using multimedia content and new possibilities given by information and communications technologies, teachers have an option of the contemporary presentation of teaching content in the style acceptable for new generations (Y-millennials and Z). Thus they can make more efficient acquiring of planned teaching content possible for them. To lay the foundation of quality and efficient learning in the right way, and at the same 
time follow the tendencies of technology development and new generations of students (pupils), it is necessary to join activities of competent people and adequate processes. Efficient learning and effective knowledge transfer bring benefits to all those involved in the process.

In newly created conditions education is changing its role as well, and new tasks given to educational institutions are related to the request of the community for young people to be adequately prepared for the world of frequented changes and be trained to find their places in such a world (Šormaz et al., 2019). In the Report of the Docebo company (Docebo S.p.A., 2020) "The trends of e-learning for companies 2020 - The new era of learning" the research carried out by the Brandon Hall Group - Learning Management Tech 2018, anticipates certain trends that will mark the year 2020, and wider. The trends are divided into four main groups related to the key fields of today's learning function, from the perspective of students and the management of business systems:

- Learning content;

- Learning experience;

- Learning automatization;

- Learning output.

In support of the above stated, there is a graph where it can unequivocally be seen that a new way of learning is demanded by students and employers which implies the implementation of the new technologies (Figure 1).

Based on the viewed results in Figure 1, but also a big number of existing researches on this subject, surely the unavoidable element of microlearning which represents the framework of the new form of education is mobile learning. Its importance can be seen through: personalization, transfer, interactivity, and contextually, then also, through games. They leave an impression of fun during learning, and their application has been growing more and more in the teaching process, especially for learning through simulation and demonstration of practical examples. The advantage of this kind of

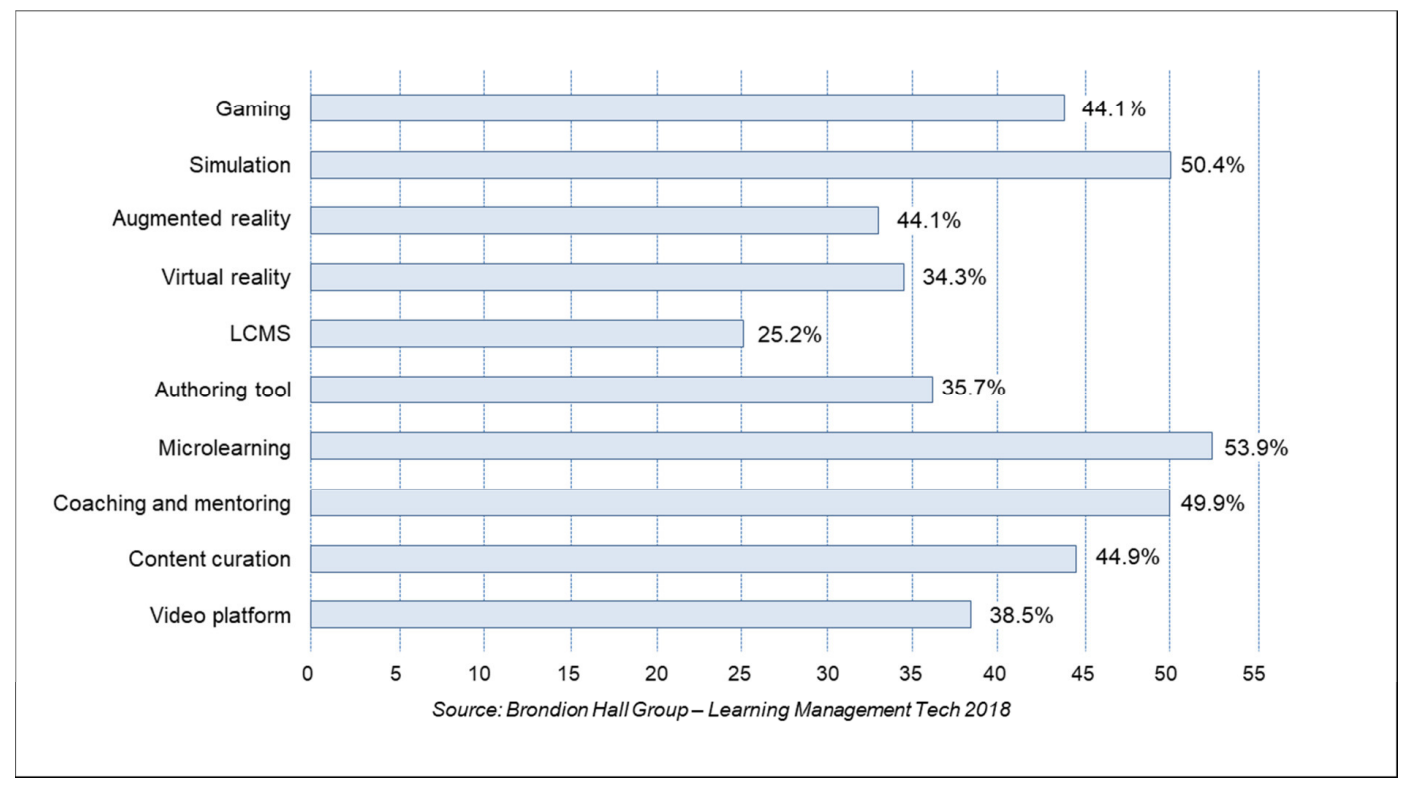

Figure 1. The most efficient software - a platform for e-learningl

\footnotetext{
${ }_{1}$ Retrieved from: https://www.docebo.com/blog/summary-enterprise-elearning-trends-2020-docebo-report/
} 
learning is the active holding of students' attention, increased motivation, as well as the fact that the educational content learned this way remains longer in the memory of students.

The carried out research of a group of authors led to the results that one of the main problems of a small number of passed exams of students was the professor's way of presenting the educational content. By this lecturing in big groups was implied, where the professors were not able to answer the students 'questions, nor to explain their lectures in detail. That resulted in the absence of students from lectures and unfulfilling of pre-exam obligations, and at the same time, not passing the exam (Pavlović et al., 2014).

Analogically to the stated, education has been surely changing in accordance with the needs of the forthcoming generations, and that should be unequivocally accepted and implemented into the system as soon as possible. Today's generations of students, especially Z (born after the year 2000) are very different compared to the previous generations. These students (pupils) are "digital natives" as they are called by the futurist Marc Prensky, because those are the generations which do not know of a different world except the information one. They have replaced the real world for the digital one and they give advantage to the virtual environment.

Joshi expresses the attitude that the multimedia application in the teaching process cannot be avoided any more (Joshi, 2012), and having in mind that the sphere of ICT has been developing at incredible speed, the teaching performed traditionally must surely be adapted to those changes.

\section{EMPIRICAL RESEARCH OF THE INFLUENCE OF ICT IN CONTEMPORARY TEACHING}

The paper presents the results of the empirical research concerning the opinion of students about the application of ICT in contemporary teaching. The research had a goal to determine whether the application of new ICT presented by multimedia content influences the effects in teaching, which in this case represents bigger satisfaction during acquiring knowledge and encouraging students to think and be productive.

\subsection{The research design}

In accordance with the research goals, the teaching model with the use of ICT was created, so that the chosen teaching subject was enriched by the current multimedia content applicable to educational purposes. Thus the teaching content was presented with the contemporary "style of expression" which is more acceptable for the new generations of students. To this effect, the empirical research was carried out of a group of students who followed classes by the application of ICT, e-learning (distance learning) (Marković Blagojević, 2018).

The research was realized on information studying subjects, specifically on the accredited studying program of Business economy and entrepreneurship at the Faculty for Busines Economics and Entrepreneurship, Belgrade, on the accredited studying programs of Management and Economics at the Business College of Applied Studies "Prof. Radomir Bojkovic, PhD" from Kruševac, then at the Technical-Technological College of Applied Studies in Kruševac (now known as the 
Academy of Applied Studies Sumadija, the Department in Kruševac), on the accredited studying program of Information technology and computer science, and the Faculty of Applied Management, Economics, and Finances, the accredited studying program of Applied information technologies. The period of realization was the winter semester of the school year 2015/16, and the number of respondents-students was 388, from the territory of the whole Republic of Serbia. (Marković Blagojević, 2018).

In the research, several scientific methods were used, and the basis of the research model is a questionnaire which comprises the relevant fields of research, dimensions, and variables. The questionnaire was created in two versions, electronic and printed (Appendix 1). A group of students was surveyed by filling out the printed questionnaires, and thus collected data were put into the web questionnaire created for this purpose on a Google disc as a Google Docs Spreadsheet document.

The other group of students was surveyed by a direct filling out of an electronic survey of a Google Docs Spreadsheet document. Thus it was possible to directly transfer the research data to a common database in Microsoft Excel 2016, and then transferred into SPSS 21.0 where the data were statistically processed. The questionnaire is anonymous, the questions were in the form of "a choice of offered options" which were previously subject to statistical checks of their validity and reliability, and within which five groups of questions were defined.

The first group referred to basic data about the student, the second group was about the design and organization of teaching, the third group of questions treated the competencies of teachers, the fourth group researched the communication of students with the teacher and the fifth group referred to the communication of students with their student peers.

The satisfaction of students was expressed with a mark on the scale from 1 to 5, (Likert scale), where 1= I completely disagree, and $5=\mathrm{I}$ fully agree. The methodological work concept was set systematically, and it included all the phases needed for the drafting of a scientific paper. The questionnaire was filled out by students after the realization of an exam from a chosen subject. The level of the response and the validity of the filled questionnaires was expected and suits the results recommended in literature (Das et al., 2000; Molina et al., 2007).

The reliability and consistency of claims were measured by the Cronbach's alpha coefficient and they range from 0 to 1 , where the preferable values of the coefficient

Table 1. Reliability and consistency of claims measured through the Cronbach's alpha coefficient

\begin{tabular}{clc}
\hline Number. & \multicolumn{1}{c}{ Activities } & $\begin{array}{c}\text { Cronbach's Alpha } \\
\text { if Item Deleted }\end{array}$ \\
\hline 1. & Design and organization of teaching & .833 \\
2. & Competencies of teachers & .826 \\
3. & Communication with the teacher & .839 \\
4. & Communication with student peers & .835 \\
5. & Average & .833 \\
\hline \multicolumn{2}{l}{ Source: The original survey research }
\end{tabular}


should be larger than 0.7 . In this case, the received values show adequate reliability and internal consistency of variables because the Cronbach's alpha coefficient for the whole model amounts to 0.833 , (Table 1 ).

The methods of descriptive statistics were used for the description of the questioned population, the average value (arithmetic mean), the measures of variabilities (standard deviation), and relative numbers. For determining the significance of the difference between the characteristics, the $\chi^{2}$ test was used. For the purpose of additional determining of theoretically supposed structure of factors, the Confirmatory Factor Analysis - CFA was used (Figures 2 and 3). CFA is trying to statistically confirm the defining of dimensions by manifest variables (Tabachnick \& Fidell, 2007).

This analysis is used for the confirmation of a theory, that is, testing of the conceptual model and hypotheses, and it represents a special kind of structural modeling, Structural Equation Modeling - SEM (Tabachnick \& Fidell, 2007). CFA approach in research implies that the examined models were assumed, that is, constructed based on theoretical assumptions about how manifest variables define constructs and how the constructs are connected (Delić, 2013).

Assumed models are statistically tested with the help of data from the sample. Goodness-of-fit Statistics - GFI is the most frequently used indicator of the total suitability of a model. It is used to compare how much a well-set model agrees with the analyzed data. The values of a GFI index range from 0 to 1 , where the higher value of the index signifies a better agreement of a model.

The values between 0.95 and 1.00 represent a good fit of a model, while the values between 0.90 and 0.95 represent the acceptable fit of a model. Adjusted Goodness-of-fit Statistic - AGFI is the indicator of suitability by which GFI is coordinated related to the levels of freedom of the analyzed model, that is, related to the model's complexity. Theoretically, the values for AGFI range from 0 to 1 , where the higher value signifies better agreement. The values created for AGFI should be close to the values created for GFI (Figures 2 and 3, Tables 2 and 3). The correlation analysis shows the volume and direction of connections between the key analytic concepts (groups) (Table 4).

In further text, the results of the stated research will be shown which are related to the application of ICT in teaching and modernizing of teaching.

\section{RESULTS}

Using the stated CFA concept, in order to see the connection between the variables from the previously mentioned questionnaire, and their connection, 6 key analytic concepts (groups) were drawn: comprehension and motivation, elearning, multimedia and social networks, the evaluation of teachers' competences, communication with the teacher, and communication with colleagues.

Variable and its description:

pld - Current teaching material contributes to a larger satisfaction of students and motivates them;

$\mathrm{p} 2 \mathrm{~d}$ - Teaching material presented comprehensively and related to practice influences easier comprehension of the educational content;

p3d - Teaching material enriched with 
Table 2. RMR, GFI, AGFI for Figure 2

\begin{tabular}{llcccc}
\hline & \multicolumn{1}{c}{ Model } & RMR & GFI & AGFI & PGFI \\
\hline 1 & Default model & .033 & .954 & .922 & .555 \\
2 & Saturated model & .000 & 1.000 & & \\
3 & Independence model & .252 & .446 & .323 & .365 \\
\hline
\end{tabular}

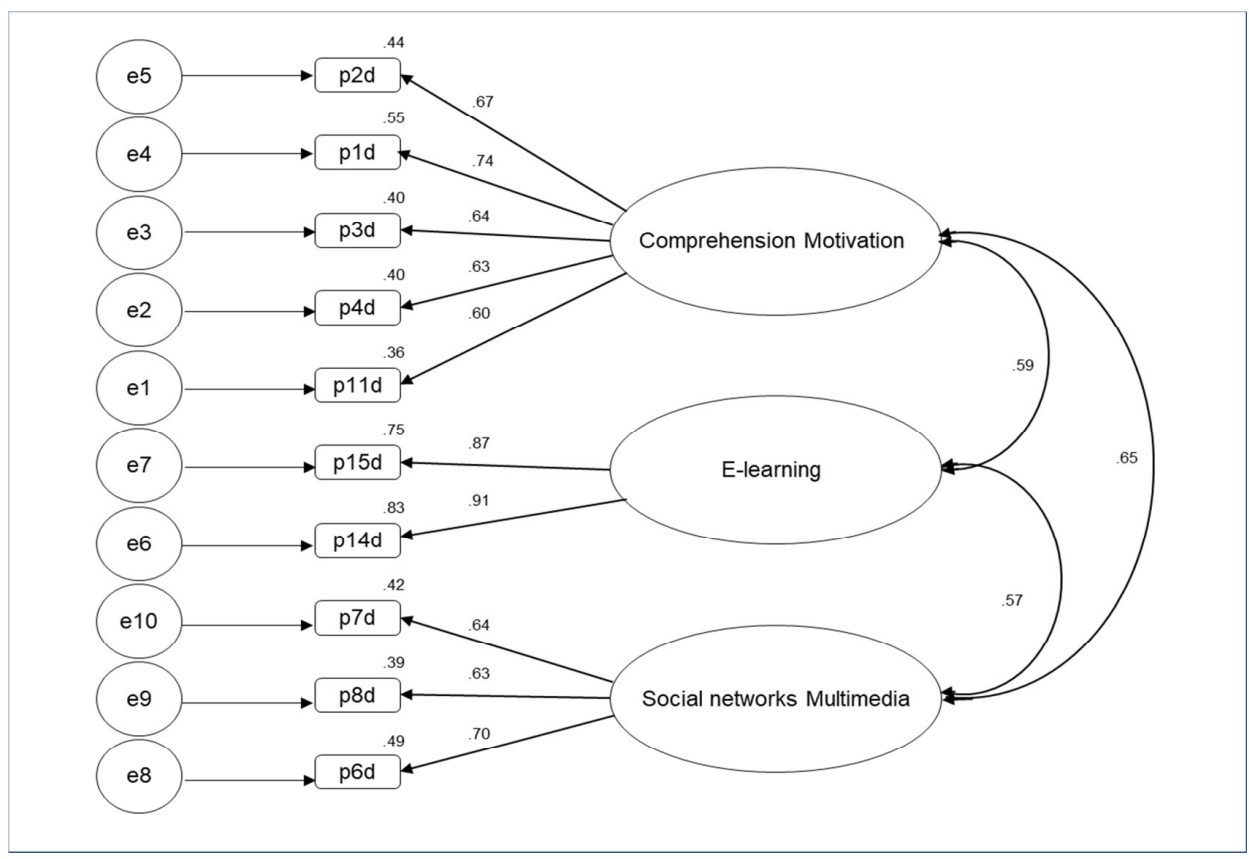

Figure 2. The influence and connection of variables for the Design and organization of teaching on three key factors Comprehension and motivation, E-learning and Social networks and multimedia

pictures and animations contributes to easier comprehension and acquiring educational content;

p4d - Teaching material presented by a presentation contributes to easier comprehension and acquiring educational content;

p5d - Teaching material presented through audio and video recordings contributes to easier comprehension and acquiring educational content;

p6d - When there is a blog created for a teaching subject with additional materials and explanations, it additionally motivates me to learn the educational content and exchange information with the teacher and student peers;

p7d - When a group is created for the teaching subject on social networks with additional materials and explanations, it additionally motivates me to learn the educational content and exchange information with the teacher and student peers;

p8d - Participating in forums enables me to exchange information and learn the educational content faster;

p9d - I learn more easily from the electronic books than from the printed books; 
p10d - I learn certain educational content more efficiently when I use the Internet for receiving additional materials and information;

p11d - Teaching material presented through practical examples contributes to easier comprehension of the educational content;

p12d - The use of mobile devices in teaching for the demonstration of practical examples contributes to larger satisfaction and motivation of students;

p13d - The use of games and programs for simulation for easier learning of educational content (gamification) contributes to larger satisfaction and motivation of students;

p14d - Teaching materials placed on the platform (site) for E-learning contribute to a more efficient organization of learning; p15d - Teaching materials placed on the platform (site) for E-learning and enriched with multimedia content contribute to the larger satisfaction of students during studying the subject.

Based on the level of correlation between the variables and justification of the factor analysis (Figure 2) it can be concluded that the existence of excellent correlations from the aspect of design and teaching organization means that:

- For good comprehension and motivation of students, the teaching material should be up-to-date, presented comprehensively, connected to practice, i.e. presented through practical examples, enriched with pictures and animations (presented by a presentation).

- Teaching materials presented on the

Table 3. RMR, GFI, AGFI for Figure 3

\begin{tabular}{llllll}
\hline & \multicolumn{1}{c}{ Model } & RMR & GFI & AGFI & PGFI \\
\hline 1 & Default model & .003 & .999 & .996 & .200 \\
2 & Saturated model & .000 & 1.000 & & \\
3 & Independence model & .264 & .480 & .133 & .288 \\
\hline
\end{tabular}

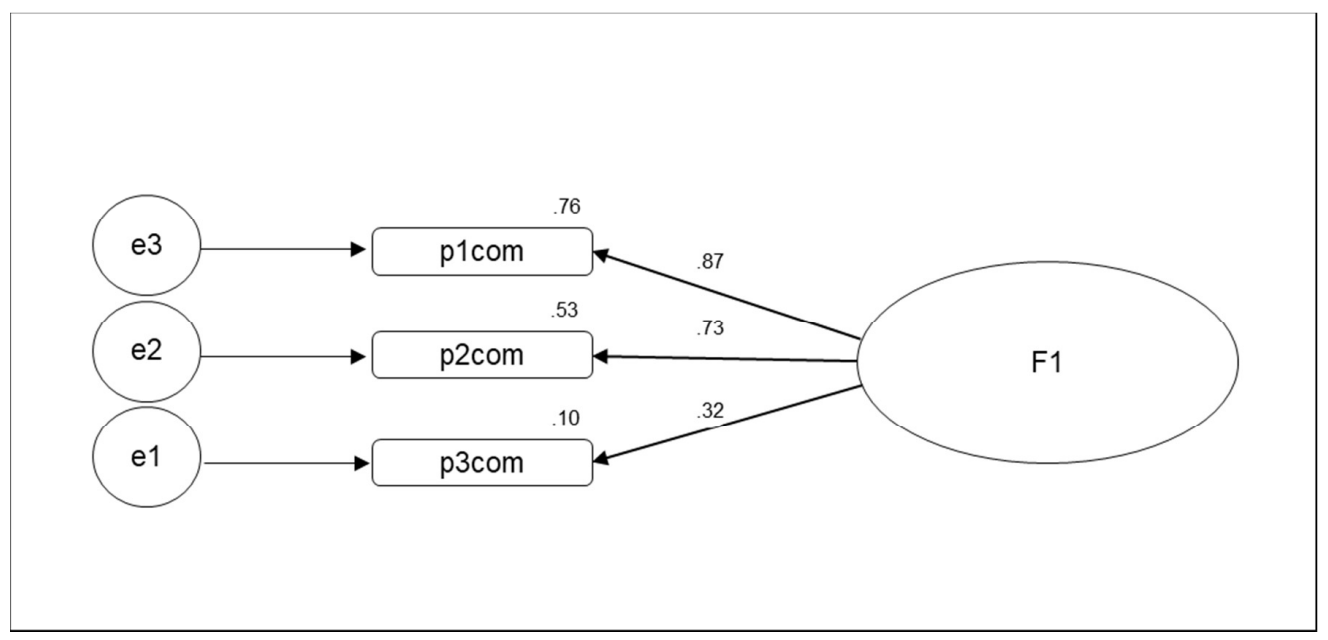

Figure 3. The influence and connection of variables for the Communication with the teacher on the key factor comprehension and motivation 
platform (site) for e-learning (distance learning) contribute to a more efficient learning organization and larger satisfaction of students during studying of subjects if they are enriched with purposeful multimedia content.

- Students are additionally motivated to learn the educational content and exchange information with the teacher and colleagues if the blog is created for the teaching subject with additional materials and explanations, a group on social networks, and participation on forums.

Variables and description:

p1com -Clearly communicated/presented topics and requests by teachers influence the satisfaction and motivation of students;

p2com - Availability of the teacher with additional explanations and help contribute to larger satisfaction and motivation of students;

p3com - Electronic communication with the teacher (e-mail, messages, Viber, forum, chat on Facebook, etc.) is more efficient than the traditional (face to face);

F1 - The main factor Comprehension and motivation.

Based on the level of correlation between the variables and justification of the factor analysis (Figure 3 ) it can be concluded by the existence of excellent correlations from the aspect of communication with the teacher that:

- For the satisfaction of students and better comprehension and motivation, it is important for the teacher to communicate/present important topics and requests clearly, as well as to be available for them for additional explanations and help. It is very important for them for communication not to happen only through electronic media, but also in the traditional way (face to face).

Based on the received results (Table 4) and received strong and positive correlations, it can be said that for the comprehension and motivation of students:

Table 4. Correlation analysis for all the key analytic concepts

\begin{tabular}{|c|c|c|c|c|c|c|c|}
\hline & & $\begin{array}{l}\text { Comprehen- } \\
\text { sion and } \\
\text { motivation }\end{array}$ & E-learning & $\begin{array}{l}\text { Multime- } \\
\text { dia and } \\
\text { social } \\
\text { networks }\end{array}$ & $\begin{array}{c}\text { Evaluation } \\
\text { of } \\
\text { competen- } \\
\text { cies of } \\
\text { teachers }\end{array}$ & $\begin{array}{l}\text { Communica- } \\
\text { tion with the } \\
\text { teacher }\end{array}$ & $\begin{array}{l}\text { Communica- } \\
\text { tion with } \\
\text { student peers }\end{array}$ \\
\hline $\begin{array}{l}\text { Comprehension } \\
\text { and motivation }\end{array}$ & $\begin{array}{l}\text { Pearson Correlation } \\
\text { Sig. (2-tailed) } \\
\text { N }\end{array}$ & $\begin{array}{r}1 \\
388\end{array}$ & $\begin{array}{r}.569 " \\
.000\end{array}$ & $\begin{array}{r}700 " \\
.000 \\
388\end{array}$ & $\begin{array}{r}.633 " \\
.000 \\
388\end{array}$ & $\begin{array}{r}.597 " \\
.000 \\
388\end{array}$ & $\begin{array}{r}.569 " \\
.000 \\
388\end{array}$ \\
\hline E-learning & $\begin{array}{l}\text { Pearson Correlation } \\
\text { Sig. (2-tailed) } \\
\text { N }\end{array}$ & $\begin{array}{r}.569 " \\
.000 \\
388 \\
\end{array}$ & $\begin{array}{r}1 \\
388 \\
\end{array}$ & $\begin{array}{r}.565 " \\
.000 \\
388 \\
\end{array}$ & $\begin{array}{r}.517 " \\
.000 \\
388 \\
\end{array}$ & $\begin{array}{r}.467 " \\
.000 \\
388 \\
\end{array}$ & $\begin{array}{r}.472 " \\
.000 \\
388 \\
\end{array}$ \\
\hline $\begin{array}{l}\text { Multimedia and } \\
\text { social networks }\end{array}$ & $\begin{array}{l}\text { Pearson Correlation } \\
\text { Sig. (2-tailed) } \\
\text { N } \\
\end{array}$ & $\begin{array}{l}.700 " \\
.000\end{array}$ & $\begin{array}{r}.562 " \\
.000 \\
388 \\
\end{array}$ & $\begin{array}{r}1 \\
388 \\
\end{array}$ & $\begin{array}{r}.517 " \\
.000 \\
388 \\
\end{array}$ & $\begin{array}{r}.492 " \\
.000\end{array}$ & $\begin{array}{r}.514 " \\
.000 \\
388 \\
\end{array}$ \\
\hline $\begin{array}{l}\text { Evaluation of } \\
\text { competencies } \\
\text { of teachers }\end{array}$ & $\begin{array}{l}\text { Pearson Correlation } \\
\text { Sig. (2-tailed) } \\
\text { N }\end{array}$ & $\begin{array}{r}.633 " \\
.000 \\
388\end{array}$ & $\begin{array}{r}.517 " \\
.000 \\
388\end{array}$ & $\begin{array}{l}.515 " \\
.000 \\
388\end{array}$ & 388 & $\begin{array}{r}.675 " \\
.000 \\
388 \\
\end{array}$ & $\begin{array}{r}.642 " \\
.000 \\
388 \\
\end{array}$ \\
\hline $\begin{array}{l}\text { Communication } \\
\text { with the teacher }\end{array}$ & $\begin{array}{l}\text { Pearson Correlation } \\
\text { Sig. (2-tailed) } \\
\text { N }\end{array}$ & $\begin{array}{r}.597 " \\
.000 \\
388\end{array}$ & $\begin{array}{r}.467 ” \\
.000 \\
388\end{array}$ & $\begin{array}{r}.492 " \\
.000 \\
388\end{array}$ & $\begin{array}{r}.675 " \\
.000 \\
388\end{array}$ & $\begin{array}{r}1 \\
388\end{array}$ & $\begin{array}{r}.631 " \\
.000 \\
388\end{array}$ \\
\hline $\begin{array}{l}\text { Communication } \\
\text { with student } \\
\text { peers }\end{array}$ & $\begin{array}{l}\text { Pearson Correlation } \\
\text { Sig. (2-tailed) } \\
\text { N }\end{array}$ & $\begin{array}{r}.569 " \\
.000 \\
388\end{array}$ & $\begin{array}{r}.472 " \\
.000 \\
388\end{array}$ & $\begin{array}{l}.514 " \\
.000 \\
388\end{array}$ & & $\begin{array}{r}.631 " \\
.000 \\
388\end{array}$ & 388 \\
\hline
\end{tabular}


- Competence of teachers and achieving good communication with them is important.

- It is preferable for the teaching materials to be presented through multimedia content and additionally enriched on social networks.

- Efficient communication is preferable among student peers and with the teacher.

To see the connection between the level of knowledge of working on a computer (Table 5) and received results, that is, to question the claim (assumption) that students who have a better knowledge of working on a computer are more interested in the implementation of ICT in teaching, the variance analysis (Anova) was applied with the variable "Knowledge of working on the computer" (independent) and group variable "Comprehension and motivation", (dependent) (Table 6).
Based on the received results shown in Table 5 it can be seen that the largest value of the arithmetic mean belongs to answers given by the students who stated that they have good knowledge of working on a computer, (as=4.17, $\mathrm{sd}=0.556)$.

Based on $F$ statistics and its statistical significance $(\mathrm{F}=4.697, \mathrm{p}=0.010<0.05 \mathrm{df}=2)$ it can be concluded that there are statistically significant differences in the students' answers who have a better knowledge of working on a computer compared to the ones who have less and medium knowledge. (Table 6) Students with more advanced knowledge in the use of computers are more open to the application of ICT in teaching.

Table 5.The Mark of the knowledge of working on a computer of the surveyed students

\begin{tabular}{|c|c|c|c|c|c|c|c|c|c|}
\hline \multirow[b]{2}{*}{ Number } & \multirow{2}{*}{$\begin{array}{l}\text { Mark of } \\
\text { knowledge } \\
\text { of working }\end{array}$} & \multirow{2}{*}{$\mathbf{N}$} & \multirow{2}{*}{ Mean } & \multirow{2}{*}{$\begin{array}{c}\text { Std. } \\
\text { Deviation }\end{array}$} & \multirow{2}{*}{$\begin{array}{l}\text { Std. } \\
\text { Error }\end{array}$} & \multicolumn{2}{|c|}{$\begin{array}{l}\text { 95\% Confidence } \\
\text { Interval for Mean }\end{array}$} & \multirow{2}{*}{$\begin{array}{l}\text { Mini- } \\
\text { mum }\end{array}$} & \multirow{2}{*}{$\begin{array}{c}\text { Maxi- } \\
\text { mum }\end{array}$} \\
\hline & & & & & & $\begin{array}{l}\text { Lower } \\
\text { Bound }\end{array}$ & $\begin{array}{l}\text { Upper } \\
\text { Bound }\end{array}$ & & \\
\hline 1 & $\mathrm{Bad}$ & 16 & 3.96 & .623 & .156 & 3.68 & 4.34 & 3 & 5 \\
\hline 2 & Medium & 87 & 4.01 & .610 & .065 & 3.83 & 4.09 & 3 & 5 \\
\hline 3 & Good & 285 & 4.17 & .556 & .033 & 4.11 & 4.24 & 2 & 5 \\
\hline 4 & Total & 388 & 4.12 & .576 & .029 & 4.06 & 4.17 & 2 & 5 \\
\hline
\end{tabular}

Table 6 Variance analysis of the influence of the knowledge of working on a computer and implementation of ICT in teaching

\begin{tabular}{|c|c|c|c|c|c|c|}
\hline & & & & & & \\
\hline & & $\begin{array}{c}\text { Sum of } \\
\text { Squares }\end{array}$ & df & $\begin{array}{c}\text { Mean } \\
\text { Square }\end{array}$ & $\mathbf{F}$ & Sig. \\
\hline 1 & Between Groups & 3.063 & 2 & 1.531 & 4.697 & .010 \\
\hline 2 & Within Groups & 125.518 & 385 & .326 & & \\
\hline 3 & Total & 128.581 & 387 & & & \\
\hline
\end{tabular}




\section{DISCUSSION}

The vital knowledge of today are certainly digital literacy and efficient use of new technology, so they can be considered a precondition when speaking of any kind of education advancement and preparation of the new generations for leading the economy of the $21^{\text {st }}$ century.

From the results of the empirical analysis, the authors may state that the opinions of the surveyed students for the use of ICT and presenting teaching material through the application of multimedia content has effects in the contemporary teaching of information technology. That influence is statistically significant especially when it comes to the improvement of the process of teaching and acquiring knowledge by students, as well as when it comes to the incentive of students to think and be productive. The results of the empirical analysis comply with the results of the theoretical analysis.

Based on the considered element in the paper so far, certain guidelines can be summarized:

- It is necessary for the higher education institutions to be directed to the application of new ways of adopting and transfer of knowledge, especially for the new $\mathrm{Y}$ and $\mathrm{Z}$ generations, and the following of the upcoming trends in education with combining with the existing traditional teaching performance.

- The exclusive use of LMS system for the organization of teaching is not necessary, at least not at this moment, but it is necessary to enrich teaching with multimedia content, with compulsory practical examples which can be presented with the use of elements of microlearning (mobile learning, use of games and programs for simulation and demonstration).
- Teamwork with students, active participation, and discussion play a big part in the motivation and satisfaction of students with teaching, and at the same time with the easier acquiring of the given educational content.

- The teacher should show the initiative and readiness for the advancement of teaching with the use of new ways for transfer and acquiring of knowledge, but it is necessary for him to be available and at the disposal of students and not only via electronic channels of communication but face to face when they need it.

- Students who have more advanced knowledge in the use of computers are more open to the introduction and application of ICT in teaching.

With the analysis of the received results presented through the stated guidelines, the authors can state that they agree with the received results of researches carried out in the world, stated in the previous part of the paper. Thus the relevancy of received data and claims is emphasized, as well as the global application of the stated guidelines for the general advancement of the teaching process and motivation of students/pupils in acquiring the planned teaching activities.

\section{CONCLUSIONS}

The basic idea of this paper was to present and analyze the opinion of students about the influence of the application of ICT and teaching material enriched with multimedia content through electronic learning using empirical research. Scientific discovery and cognition have been reached regarding motivation, approach, mastering, and comprehension of teaching content by students and they are: 
- It is easier for students to understand and master educational content with good communication with a teacher, through teaching content presented by practical examples;

- Availability of the teacher for additional explanations and help motivate students and increase their satisfaction;

- Current teaching material presented comprehensively, by using multimedia content and connected to practice influences easier comprehension of the educational content;

- Teaching materials placed on a platform for e-learning, enriched with multimedia content contribute to a larger satisfaction of students during studying the subjects and a more efficient learning organization;

- The use of mobile devices in teaching, as well as games and programs for simulation and demonstration of practical examples, contribute to a larger satisfaction and motivation of students;

- Competencies and skills of teachers influence the comprehension of educational content, acquiring knowledge, satisfaction, and motivation of students;

- The motivation of teachers for the innovative application of the new methods and techniques for more efficient transfer and acquiring educational content, as well as the ability of application multimedia content influence the satisfaction and motivation of students;

- Students disagree that electronic communication with the teacher is equally efficient as the traditional one (face to face);

- Students possessing more advanced knowledge in the use of computers are more open to the use of ICT in teaching.

The originality of this research, compared to other researchers who dealt with this field lies exactly in joining and cooperation of several higher education institutions in the Republic of Serbia, to get the more relevant picture and opinions of students about the most efficient way of performing teaching activities, regardless of the starting variables of the respondents (gender, age, profile, information literacy, and location).

The scientific contribution of this paper has enabled quality and deep insight into the current situation in the field of ICT application in the teaching processes of the distance learning system. It was proved that students who have more advanced knowledge in the use of computers are more open to the application of multimedia and interactive methods of online learning and ICT application. The received results can be applied in educational practice so that the teaching processes can be modernized and brought closer to students. Also, the performed research can be taken as a starting point for the future, more detailed researches of this subject, with a goal to achieve a more efficient reform and advancement of higher education, especially in the part regarding electronic learning in the Republic of Serbia, as well as in the world.

\section{References}

Akin E., Cecen M.A., (2015). Multimedia-Based Turkish Teaching and Student Views on Multimedia Tools. Turkish. Stud.10 (7): 51-72.

Bacaron, C., \& Cantona, Z., (2018). The Impact of Multimedia Glossing on Expanding the Vocabulary Knowledge of Grade 10ESL Students from Paco Catholic School through Constructivist Approach, De La Salle University-Manila. Retreived from t.ly/c9pV.

Biesta, G. (2016). ICT and Education 


\title{
ИНФОРМАЦИОНЕ И КОМУНИКАЦИОНЕ ТЕХНОЛОГИЈЕ И МУЛТИМЕДИЈАЛНИ САДРЖАЈ КАО МОТИВАЦИОНИ ФАКТОРИ ЗА НОВЕ ГЕНЕРАЦИЈЕ УЧЕНИКА
}

\author{
Марија Марковић Благојевић, Зорица Медић, Маја Цогољевић, \\ Раица Милићевић
}

\section{Извод}

Овај рад се бави теоријском анализом принципа ефикасне употребе информационокомуникационих технологија (ИКТ) у настави и учењу, што може допринети унапређењу наставног процеса и мотивацији ученика у постизању планираних активности. У раду су, поред теоријске анализе, представљени и резултати емпиријских истраживања. Њима је тестирано и практично потврђено да постоји значајан утицај примене ИКТ-а и обогаћивања наставног материјала мултимедијалним садржајем, као и ефеката у савременој настави о информационим технологијама. Примарна намера овог рада је да укаже на значај увођења ИКТ у наставни процес са циљем значајног побољшања учења ученика кроз повећање њихове мотивације и ефикасности у учењу, а истовремено дугорочно побољшање перформанси образовног система.

Кључне речи: ИКТ, образовање, унапређење наставе, мултимедијални садржаји, ефикасно учење

Beyond Learning. In: Elstad E. (eds) Digital Expectations and Experiences in Education. SensePublishers, Rotterdam.

Buda, A. (2014). ICT in Education. In J. Kapounová (Ed.), Information and Communication Technologies in Education Overview in Visegrad countries. University of Ostrava, Ostrava, Czech Republic.

Budić, S. (2006). Characteristics of students' knowledge in the teaching process (in Serbian). International interdisciplinary conference, European dimensions of the reform of the education system, Novi Sad, Serbia, 180-185.

Cairncross, S., \& Mannion M. (2001). Interactive multimedia and learning: Realizing the benefits. Innovations in education and teaching international, 38 (2), 156-164.

Cekić-Jovanović, O. (2015). The efficacy of multimedia in teaching science and society (Doctoral dissertation - in Serbian), University of Novi Sad Faculty of Philosophy, Retrieved from https://nardus.mpn.gov.rs/handle/123456789 14817.

Cheng, I., Basu, A., \& Goebel, R., (2009). Interactive Multimedia for Adaptive Online Education. IEEE MultiMedia, 16(1), 16-25.

Chittaro, L., \& Ranon, R. (2007). Web 3D technologies in learning, education and training: Motivations, issues, opportunities. Computers \& Education, 49 (1), 3-18.

Das, A., Handfield, R.B., Calantone, R.J. and Ghosh, S. (2000). A contingent view of quality management-the impact of international competition on quality. Decision Sciences, 31(3), 649-690.

Delić, M. (2013). Influence of management system and application of 
information technologies on the performance of the organization (in Serbian). Novi Sad: University of Novi Sad, Faculty of Technical Sciences.

Ilhan, G.O., \& Oruç, Ş. (2016). Effect of the use of multimedia on students' performance: A case study of social studies class. Educational Research and Reviews, 11 (8),

877-882.

https://doi.org/10.5897/ERR2016.2741

Joshi, A. (2012). Multimedia: A technique in teaching process in the classrooms. Current World Environment, 7 (1), 33-36.

Marković Blagojević, M. (2018). New information - communication technologies in improving the function of higher education (Doctoral dissertation - in Serbian). University Business Academy in Novi Sad, Faculty of Applied Management, Economics and Finances. Retrieved from https://nardus.mpn.gov.rs/handle/123456789 /10403

Marković Blagojević, M., Medić, Z., \& Živadinović, J. (2019). Competences of teaching staff for the implementation of elearning in higher education (in Serbian). The third national scientific-professional conference with international participation "Trends in Business 2019", Kruševac, Serbia.

Matijašević-Obradović, J., Škorić, S., \& Kovačević, M. (2018). Strategic treatment of ICT application in education (in Serbian). XXIV conference Development trends "Digitalization of higher education", Kopaonik, Serbia. Paper No.T1.2-3.

Mayer, E.R. (2017). Using multimedia for e-learning. Journal of Computer Assisted Learning, 33 (5), 403-423.

Molina, M.L., Llorens-Montes, J., \& Ruiz-Moreno, A. (2007). Relationship between quality management practices and knowledge transfer. Journal of Operations
Management, 25 (3), 682-701.

Nabil, A., Awerbuch, B., Slonim, J., Wegner, P., \& Yesha Y. (1997): Globalizing business, education, culture through the Internet. Communications of the ACM, 40 (2), 115-121.

Naps, T., Bergin, J., Jimenez-Peris, R., McNally, M.F., Patino-Martinez, M., Proulx, V.K., \& Tarhio, J. (1997). Using the WWW as the Delivery Mechanism for Interactive, Visualization-based instructional modules. Conference on Integrating Technology into Computer Science Education, (ITiCSE'97), Uppsala, Sweden, June 1997, 13-26.

OECD (2019), TALIS 2018 Results (Volume I): Teachers and School Leaders as Lifelong Learners, TALIS, OECD Publishing, Paris, Retrieved from https://doi.org/10.1787/1d0bc92a-en

Patrick, S. (2008). ICT in Educational Policy in the North American Region. In: J. Voogt, G. Knezek (eds) International Handbook of Information Technology in Primary and Secondary Education. Springer International Handbook of Information Technology in Primary and Secondary Education, vol 20. Springer, Boston, MA., 1109-1117.

Pavić, Ž. (2019). Health management education e-learnning model (in Serbian). Ekonomika, 65 (1), 85-94.

Pavlović, D., Todorović, M., Mladenović, S., \& Milosavljević, P. (2014). Uloga metoda kvaliteta u poboljšanju procesa obrazovanja studija slučaja. Serbian Journal of Management, 9 (2), 219-230.

Tabachnick, B. G., \& Fidell, L. S., 2007. Using Multivariate Statistics. Boston: Pearson Education, Inc.

The strategy of education development in Serbia until 2020 (in Serbian). (2012). Official Gazette of RS, no. 107/2012 Retrieved from http://www.mpn.gov.rs/wp- 
content/uploads/2015/08/STRATEGIJAOBRAZOVANJA.pdf

Šormaz, G., Anđelić, S., \& Marković Blagojević, M. (2019). Designation of modern management in education (in Serbian), Trendovi u poslovanju, 7 (1), 3748.

Docebo S.p.A., (2020): „Enterprise ELearning Trends 2020 - A New Era of Learning" Retrieved from https://www.docebo.com/blog/summaryenterprise-elearning-trends-2020-doceboreport/, pristup:20.12.2019. 